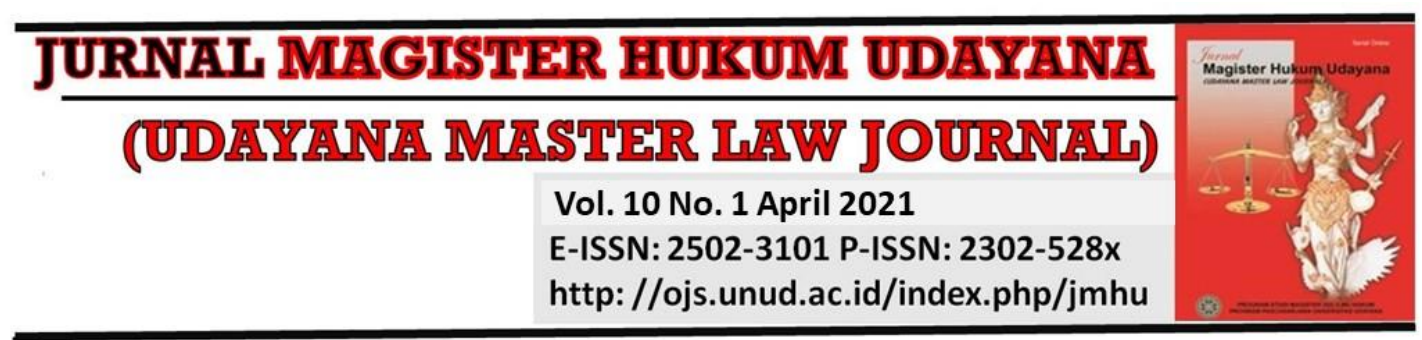

\title{
Hak Cipta Sebagai Agunan Kredit Bank
}

\author{
Angelina Putri Suhartini' ${ }^{1}$, Dewa Gde Rudy ${ }^{2}$
}

1Fakultas Hukum Universitas Udayana, E-mail: angelinaputri20@gmail.com ${ }^{2}$ Fakultas Hukum Universitas Udayana, E-mail: dewarudy1959@gmail.com

\begin{tabular}{l}
\hline Info Artikel \\
Masuk: 20 Januari 2021 \\
Diterima: 4 April 2021 \\
Terbit: 9 April 2021 \\
Keywords: \\
Copyright; Collateral; Credit \\
\\
\\
Corresponding Author: \\
Angelina Putri Suhartini, \\
Email: \\
angelinaputri20@gmail.com \\
p08 \\
Kata kunci: \\
Hak Cipta; Agunan; Kredit \\
C.2484MH.2021.v10.i01. \\
\end{tabular}
p08

\begin{abstract}
The general purpose of this research is to find out the criteria of copyright as collateral. In addition, the mechanism of copyright execution in case of debtor's default was also investigated. In this study, normative legal method was applied using the statute approach and legal concept analysis in which the vague norm was initially examined. The regulation concerning copyright as collateral is stipulated in Article 16 paragraph 3 of Copyright Law. This study showed that copyright could be used as fiduciary collateral since it is an intangible moving object and a collateralizable economic right. The stipulation on copyright as fiduciary collateral has been in accordance with the provision of encumbrance, registration, and transfer of fiduciary collateral stipulated in Law Number 42 of 1999 on Fiduciary. Due to the absence of regulation on the procedure of fiduciary encumbrance on copyrights, several criteria are used to determine the economic value of a copyright. Among other criteria, the copyright should be registered in the Directorate General of Intellectual Property of Ministry of Law and Human Right, containing an economic value and should be liable, managed by a collective management institution to find out the royalty value, and providing another form of security in the form of personal guarantee to protect such copyright. Based on Article 29 paragraph (1) of Law Number 42/1999 on Fiduciary, when a debtor is deemed default, the execution of the copyright can be carried out through executorial title, public auction, and private sale.
\end{abstract}


mengatur secara lanjut perihal tata cara pembebanan dari fidusia terhadap hakcipta, terdapat beberapa macam dari kriteria yang diperoleh menjadi acuan dasar dari penilaian ekonomis hak cipta menjadi jaminan dari kredit, diantaranya: harus dicatatkan di Direktorat Jendral Kekayaan Intelektual Kementrian Hukum HAM, mempunyai nilai yang ekonomis dan bisa dipertangungjawabkan, di kelola lembaga Manajemen Kolektif agar nilai royalti mampu diketahui, memberikan jaminan yang lain dalam bentuk personal guarantee perusahaan yang melindungi karya cipta tersebut. Berdasarkan Pasal 29 ayat (1) UU 42 No. 1999 tentang Jaminan Fidusia, apabila debitur setelah disepakati para pihak, dipandang wanprestasi, eksekusi terhadap hak cipta dapat dilakukan dengan cara pelaksanaan titel eksekutorial, menjual atas kekuasaan sendiri melalui pelelangan umum dan penjualan di bawah tangan.

\section{Pendahuluan}

Hak Kekayaan Intelektual (HKI) adalah hak untuk menikmati nilai ekonomis dari suatu kreativitas intelektual manusia, yang dalam perkembangannya semakin bernilai ekonomis dan dapat diperjualbelikan. Obyek HKI yaitu karya yang timbul atau lahir dari kemampuan intelektual manusia, yang terdiri dari hak cipta, hak paten, hak merek, hak desain industri, hak desain tata letak sirkuit terpadu, hak rahasia dagang dan hak varietas tanaman. Pasal 108 Undang-Undang No. 13 Tahun 2016 tentang Paten (UU Paten) dan Pasal 161 ayat (3) Undang -Undang No.28 Tahun 2014 tentang Hak Cipta (UU Hak Cipta) mengatur bahwa hak paten dan hak cipta dapat digunakan sebagai obyek jaminan fidusia. Dalam pemberian kredit, Undang-undang No 7 Tahun 1992 tentang Pokok Perbankan menjelaskan bahwa kredit merupakan penyediaan uang atau pun tagihan yang dapat disamakan dengan itu. Sesuai kesepakatan dalam hal pinjam meminjam antara pihak bank dengan pihak lain, dalam hal ini masyarakat, pihak peminjam harus membayar pada masa yang telah ditentukan sesuai jumlah bunga yang disepakati sebagai imbalan. Agar kredit dapat berjalan dengan lancar, ada 5 unsur yang harus terjadi untuk memperhatikan unsur kehati-hatian bank dalam memberikan kredit terhadap nasabahnya, yaitu kepercayaan, kesepakatan, jangka waktu, risiko serta balas jasa.

Pembangunan ekonomi, adalah program yang disertakan dalam pembangunan nasional dalam rangka mewujudkan kehidupan masyarakat Indonesia yang sejahtera secara merata dan berkeadilan menurut Pancasila dan UUD NRI Tahun 1945. Semakin pesatnya peningkatan kegiatan pembangunan, diiringi pula dengan peningkatan kebutuhan untuk dana, dimana dana yang dibutuhkan sebagian besar adalah untuk mencukupi berbagai keperluan yang didapatkan dari jasa peminjaman. Ada beberapa pihak yang terlibat dalam satu kegiatan pinjam-meminjam, yaitu pihak yang memberikan pinjaman dan pihak yang meminjam dana. Didalam kegiatan pinjam meminjam dana pada umumnya diperlukan syarat yang harus dipenuhi yaitu memberikan jaminan utan. Biasanya, jaminan ini berupa benda yang mempunyai nilai ekonomis padanya. Syarat menyerahkan jaminan adalah kewajiban dari pihak 
peminjam yang pada dasarnya didasari oleh kesepakatan awal dari kedua belah pihak yang terlibat didalamnya. ${ }^{1}$

Pada umumnya penyerahan jaminan utang yang dipersyaratkan untuk pemberi pinjaman dan merupakan satu kewajiban dasar, dimana jaminan dapat dalam bentuk barang (benda) ataupun dalam bentuk kesepakatan penanggungan utang. Seperti halnya objek jaminan utang yang biasanya diaplikasikan pada perjanjian utangpiutang. Benda yang dapat dijadikan barang jaminan secara umum dapat dikategorikan kedalam 3 bagian, diantaranya benda yang bergerak, benda tak bergerak, serta jaminan perorangan. Menurut peraturan yang tercantum pada UU No. 42 tahun 1999 tentang Jaminan Fidusia (selanjutnya disebut UU Jaminan Fidusia), yang dimaksud dengan benda bergerak adalah benda berwujud dan tak berwujud. Contoh dari benda yang bergerak dan tak berwujud adalah hak. ${ }^{2}$

Hak Kekayaan Intelektual ialah hak ekonomis untuk seorang pencipta atau penemu menurut hukum kepada hasil ciptaannya atau karyanya dan juga kemampuan intelektualnya. Didalam pengembangan usahanya individu yang memperoleh Hak Kekayaan Intelektual memerlukan dana untuk digunakan sebagai modal dan juga investasi pada usaha yang dilakukannya. Dalam hal ini, pelaku ekonomi kreatif dapat memperoleh dan juga mendirikan usaha rintisan ataupun melalui kegiatan pinjam meminjam baik dengan lembaga bank maupun non-bank.

Secara lebih spesifik, Hak Cipta termasuk barang yang dikelompokkan sebagai benda tidak berwujud. Menurut UU No. 28 Tahun 2014 tentang Hak Cipta (selanjutnya disebut UUHC) bahwa Hak Cipta merupakan hal baru yang dapat dimasukkan atau dijadikan sebagai Objek Jaminan Fidusia. Untuk Hak Cipta hingga saat ini selain belum masuk dalam daftar jaminan, tidak ada juga pedoman untuk menilai yang dapat diterapkan oleh Penilai Publik, maka dari itu Hak Cipta masih ditolak oleh lembaga keuangan untuk digunakan sebagai benda jaminan. Peraturan pemerintah yang lebih lanjut mengatur tentang metode pengikatan fidusian untuk Hak Cipta masih belum dibuat. Tentang Hak Cipta yang terdapat pada Pasal 16 Ayat 1 dan 3 UUHC diartikan benda bergerak tak berwujud yang dapat digunakan sebagai objek Jaminan Fidusia. Menurut peraturan baru itu maka semua hasil cipta yang dibuat oleh penciptanya dapat digunakan sebagai jaiminan. Walaupun demikian, adanya peraturan baru tersebut tidak langsung begitu saja menjadikan pencipta lebih mudah memasukkan hasil karya ciptanya kedalam daftar sebagai objek jaminan, karena masih tidak ada peraturan lebih jauh terkait hal itu.

Dengan demikian, undang-undang hak cipta sudah lama menjadi perdebatan antara pembuat undang-undang, pemegang hak cipta, dan pemberi lisensi. Dengan kemajuan terbaru dalam inovasi teknologi terkait konten berhak cipta, kekurangannya menjadi semakin terlihat. Sistem perizinan karya-karya yang telah dihasilkan oleh penciptanya yang tidak efisien merupakan ancaman yang sah terhadap inovasi, stabilitas, dan masa depan industri dan seni secara keseluruhan.

Hak cipta yang dimiliki oleh seseorang yang dapat dijaminkan adalah yang mempunyai surat atau tanda keabsahan yang berkuatan hukum. Setiap pencipta disarankan untuk mencatatkan hasil karya ciptanya agar mendapatkan hak-haknya

\footnotetext{
${ }^{1}$ S E M Bahsan SH, Hukum Jaminan Dan Jaminan Kredit Perbankan Indonesia (Rajawali pers, 2020)., h. 4.

${ }^{2}$ Ibid., h. 108.
} 
sebagai pencipta dan memperoleh keuntungan dan posisi yang lebih bernilai agar dapat digunakan dimasa yang akan datang.

Disamping nilai ekonomis suatu Hak Cipta, juga tidak mudah untuk menetapkan orang yang mempunyai hak sebagai Pemberi Fidusia. Walaupun untuk Hak Cipta, perlindungan yang digunakan menerapkan sistem deklaratif atau perlindungan yang tidak mengharuskan adanya pendaftaran, namun dalam rangka menghasilkan perlindungan yang kuat terhadap Hak Ekonomi atas karya ciptaannya, dengan demikian para pencipta disarankan untuk mencatatkannya kepada Dirjen HAKI Kemenkumham untuk menentukan pihak yang mempunyai hak menjadikan Hak Cipta sebagai objek jaminan dengan kepastian hukum yang sah.

Hak Cipta sebagai Objek jaminan fidusia dijelaskan dalam Pasal 16 Ayat 3 yang menjelaskan hak cipta adalah salah satu objek jaminan fidusia. Aturan yang disebutkan itu masih memerlukan penjelasan yang lebih lengkap dan jelas, terkait diperbolehkannya digunakan sebagai objek jaminan fidusia yaitu jenis hak cipta apa saja dan dalam kondisi apa dapat dipakai sebagai jaminan. Hak cipta yang dimiliki oleh seseorang dapat dijaminkan adalah yang mempunyai surat atau tanda keabsahan yang berkuatan hukum. Setiap pencipta disarankan untuk mencatatkan hasil karya ciptanya agar mendapatkan hak-haknya sebagai pencipta dan memperoleh keuntungan dan posisi yang lebih bernilai agar dapat digunakan dimasa akan datang.

Di Indonesia, penggunaan hasil karya cipta sebagai objek jaminan fidusia memang masih termasuk hal baru yaitu setelah adanya UU Nomor 28 Tahun 2014. Pengaturanya juga masih tidak jelas dan menyeluruh. Masalah yang dihadapi terkait hal tersebut di Indonesia yaitu belum dibuatnya peraturan khusus tentang pemanfaatan hak cipta menjadi jaminan dalam kegiatan pinjam meminjam yang melibatkan lembaga peminjam uang dan juga tidak adanya lembaga penilai yang mempunyai kapasitas dalam mengukur nilai ekonomi hak cipta yang dibuat. Dinegara lain misalnya Amerika Serikat, hak cipta dapat digunakan sebagai barang jaminan yang berbentuk barang bergerak tidak berwujud sudah diatur secara khusus. ${ }^{3}$

Untuk menentukan jenis jaminan, didalam hukum jaminan adalah berdasarkan objek jaminannya. Apabila objek jaminan dalam bentuk benda yang tidak bergerak seperti dijelaskan UU No. 4 Tahun 1996 yang memasukkan tanah sebagai objek jamunan kecuali bangunan milik orang lain yang berada diatas tanah pihak lainnya dikenakan beban Hak Tanggungan. Terdapat dua jenis jaminan untuk barang bergerak yakni gadai dan fidusia. Pasal 1150-1161 KUHPerdata secara khusus mengatur tentang gadai. Jika mengacu pada Pasal 1 butir 2 UU No.42 Thn 1999, bahwa walaupun sudah ada didalam undang-undanga namun lembaga keuangan masih belum menggunakan hak cipta sebagai jaminan hanya bila berlandaskan pada ketentuan undang-undang.

Masih terdapat beberapa isu hukum terkait penggunaan hak cipta sebagai objek jaminan fidusia didalam pelaksanaannya yang mencakup lingkupan permasalah mengenai pemilih, peralihak dan permohonan hak cipta sebagai objek jaminan. Munculnya berbagai isu hukum karena peraturan yang secara spesifi mengatur tentang jenis hak cipta dapat digunakan sebagai objek jaminan masih belum ada. Hal

\footnotetext{
${ }^{3}$ Made Bagus Satria Yudistira, "Pengaturan Hukum Sertifikat Hak Atas Merek Sebagai Jaminan Fidusia Dalam Proses Pengajuan Kredit Di Perbankan Berdasarkan Undang-Undang Nomor 20 Tahun 2016," Jurnal Magister Hukum Udayana (Udayana Master Law Journal) 6, no. 3 (2017): 310-22.
} 
tersebut tentunya mengakibatkan resiko untuk pihak lembaga peminjaman uang menjadi cukup besar apabila memperbolehkan objek jaminan berupa hak cipta.

Berdasarkan uraian latar belakang ini, terdapat beberapa isu hukum yang menarik bagi peneliti untuk dikaji lebih lanjut yaitu tentang kriteria hak cipta yang dapat digunakan sebagai jaminan dan mekanisme eksekusi hak cipta jika debitur melakukan wanprestasi. Penelitian ini juga bertujuan untuk menjawab pertanyaan tentang kelayakan hak cipta menjadi jaminan fidusia dan apakah implementasi penggunaan Hak Cipta sebagai jaminan itu sudah mematuhi peraturan atau kriteria yang tepat,

\section{Metode Penelitian}

Metode penelitian dari artikel ini yaitu metode penelitian hukum normatif didasari ketidakjelasan aturan, menerapkan pendekatan perundang-undangan serta analisis konsep hukum. Penelitian menggunakan bahan hukum primer yang berupa KUH Perdata, UUHC, UU Jaminan Fidusia dan bahan hukum sekunder yang berupa literatur hukum, dan karyatulis yang relevant. Untuk mengumpulkan data penelitian maka digunakan teknik penelitian snow ball method dengan mengacu pada bahan hukum yang sudah ada. Untuk dapat menjawab masalah hukum yang diangkat maka digunakanlah bahan hukum pertama yang relevan, langkah berikutnya yaitu mencari bahan hukum kedua dengan menggunakan daftar pustaka. Selanjutnya analisis kajian akan disajikan melalui desktriptif-analitis.

\section{Hasil dan Pembahasan}

\subsection{Kriteria Hak Cipta Yang Dapat Digunakan Sebagai Jaminan}

Hak cipta merupakan hak kebendaan bergerak yang tak berwujud. Hak cipta hanya diberikan untuk karya yang merupakan ide ataupun gagasan dengan karakteristik yang khas dan memperlihatkan originalitasnya sebagai ciptaan yang dihasilkan oleh seseorang dengan kemampuan, kreatifitas dan keahlian yang dimilikinya. Pada prinsipnya, hak cipta ialah hak yang diberi kepada seorang pencipta untuk menggunakannya dengan berbagai karya cipta yang dibuatnya. ${ }^{4}$ Menurut hukum Kekayaan Intelektual, sistem perlindungan yang berlaku berbagai hak yang dimasukkan dalam subjek, objek perlindungan seperti hak cipta, dan tindakan pihak lainnya dan juga pembuat hasil karya cipta atau pemegang hak cipta jika dipegang pihak lainnya diketahui melakukan pelanggaran. ${ }^{5}$

Hak cipta adalah hak milik yang terdapat dalam berbagai karya, misalnya karya sastra, karya seni, karya musik, rekaman suara, film dan siaran memberikan hak kepada pemegang hak cipta untuk diberi kredit atas karya tersebut, untuk menentukan siapa yang dapat menyesuaikan karya tersebut ke bentuk lain, yang dapat melakukan pekerjaan, yang dapat memperoleh keuntungan finansial darinya, dan terkait lainnya. Perlindungan hak cipta juga termasuk untuk buku, pamlet dan juga hasil karya tulis misalnya, materi kuliah, ceramah, materi pidato, dan tulisan lainnya; alat contoh

\footnotetext{
${ }^{4}$ Reni Budi Setianingrum, "Mekanisme Penentuan Nilai Appraisal Dan Pengikatan Hak Cipta Sebagai Objek Jaminan Fidusia," Jurnal Media Hukum 23, no. 2 (2016): 229-38.

${ }^{5}$ Sudjana, "Perlindungan Hak Cipta Menurut UU. No. 28 Tahun 2014 Berdasarkan Sudut Pandang Cyber Law.," Jurnal Fakultas Hukum Universitas Katolik Parahyangan 9, no. 2 (2016): 1-5.
} 
peragaan, untuk digunakan dalam pengembangan pendidikan dan juga ilmu pengetauan; musik ataupun lagu yang menggunakan teks ataupun tidak, tarian, koreografi, hasil karya lukis, gambar, hasil karya ukir, kaligrafi, seni patung, pahat, ataupun kolase; rancangan arsitektur, peta dan juga seni gambar motif lainnya, yang mempunyai masa berakhir hingga pencipta meninggal dunia dan berlangsung sampai dengan 70 tahun sesudah penciptanya disebut meninggal dunia, dihitung sejak tanggal 1 Januari tahun depan.

Maksud dari hak cipta adalah untuk memajukan kemajuan pengetahuan dengan memberikan insentif ekonomi kepada pengarang suatu karya untuk membuat karya baru. Hak Cipta adalah peraturan hukum yang memberikan perlindungan monopoli dalam bentuk terbatas untuk karya tulis dan kreatif yang dibuat dalam bentuk nyata (materi) bentuk. Hak cipta muncul segera setelah sebuah karya dibuat dengan cara tetap, dan tidak mencakup baik ide, prosedur, proses, metode operasi, konsep, prinsip atau penemuan, kecuali ditetapkan dalam bentuk yang nyata. Oleh karena itu, baginya selama ciptaan itu dibuat dan diperbaiki dalam bentuk permanen, maka ciptaan tersebut berhak untuk dilindungi hak cipta.

Hak Cipta adalah tentang melindungi ciptaan asli ciptaan yang ditetapkan dalam bentuk berwujud atau media ekspresi yang mereka dapat dirasakan, dibuat, diedarkan langsung atau tidak dengan berbagai media misalnya perangkat atau mesin. Dengan memasukkan kata-kata, "dengan bantuan mesin atau perangkat" ini berarti penulis bermaksud untuk menyertakan hak cipta, makna dalam lingkungan digital sebagai kenyataan bahwa saat ini karya seni dan sastra atau karya lainnya sedang digunakan pada perangkat elektronik dengan bantuan mesin. ${ }^{6}$ Misalnya program software, musik, puisi, artikel dan jurnal, koran. Hak cipta sesuai dengan prinsip-prinsip perlindungan hak cipta. Artinya, Hak Cipta adalah sebuah perlindungan ekspresi ide dan bukan ide itu sendiri. Dimana perlindungan tersebut hanya akan berlangsung untuk jangka waktu terbatas. Ketika jangka waktu tersebut berakhir, karya tersebut masuk ke dalam domain publik. Seseorang yang secara sah memperoleh salinan dari sebuah karya berhak cipta dapat dengan bebas menjual atau mentransfer salinan tersebut.

Pasal 57 hingga pasal 63 UU. No. 28 Thn 2014 mengatur tentang jangka waktu perlindungan atau masa berlaku Hak Cipta. Masing-masing jenis hak cipta memiliki perbedaan tentang masa berlakunya, seperti atas karya cipta buku, lagu atau musik berdasarkan ketentuan Pasal 58 ayat (1) berlaku selama hidup pencipta dan berlaku sampai 70 tahun pembuatnya dinyatakan meninggaldunia. Sementara itu untuk jenis ciptaan fotografi jangka waktu perlindungannya hanya 50 tahun sejak ciptaan pertama kali dilakukan pengumuman atas karya cipta tersebut. Dengan mencermati ketentuan UU. No. 29 Thn 2014 secara lebih detail maka bisa dipahami bahwa masing-masing ciptaan jangka waktu perlindungannya berbeda.

Dengan demikian, undang-undang hak cipta telah lama menjadi perdebatan antara pembuat undang-undang, pemegang hak cipta, dan pemberi lisensi. Dengan kemajuan terbaru dalam inovasi teknologi terkait konten berhak cipta, kekurangannya menjadi semakin terlihat. Sistem perizinan karya-karya yang telah dihasilkan oleh penciptanya

6 Bhinneka Wahyudi Palito Sitanggang, "ROYA PARTIAL TERHADAP OBYEK HAK TANGGUNGAN DALAM PERJANJIAN KREDIT KONSTRUKSI DI PT. BANK NEGARA INDONESIA (PERSERO), Tbk, KANTOR CABANG SEMARANG” (UNIVERSITAS DIPONEGORO, 2010). 
yang tidak efisien merupakan ancaman yang sah terhadap inovasi, stabilitas, dan masa depan industri dan seni secara keseluruhan.

Hak Cipta atas Ekspresi Budaya Tradisional yang dimiliki oleh negara seperti dicantumkan pada Pasal 38 ayat (1) UU No. 28 Thn 2014, berlaku selamanya. Dimana apabila terdapat ciptaan yang pembuatnya tidak diketahui siapa orangnya maka hak ciptanya akan dipegang oleh negara. seperti dijelaskan dalam Pasal 39 ayat (1) dan ayat (3) bahwa ada batasan waktu dari sejak diumumkan untuk pihak yang hendak menyatakan bahwa hak cipta atas karya cipta suatu benda terletak padanya. Pasal 39 ayat (2) menjelaskan bahwa durasi untuk menunggu seseorang atau satu pihak menyatakan haknya atas sebuah ciptaan berlaku dalam kurun waktu 50 tahun sejak pengumuman dilakukan pertama kali. ${ }^{7}$

Agar suatu karya dapat dianggap berhak cipta, karya tersebut harus asli, ditetapkan dalam bentuk materi, dan memiliki tingkat kreativitas minimal. Berdasarkan undangundang saat ini, hak cipta atas karya asli diberikan segera setelah fiksasi. Namun, hak cipta otomatis ini tidak mengizinkan pemegangnya untuk menegakkan atau melindungi materinya dari pelanggaran hak cipta melalui proses pengadilan. Setelah pemegang hak secara resmi mendaftarkan hak cipta mereka ke kantor HAKI para pemegang hak cipta diberikan beberapa hak tambahan. Hak cipta terdaftar memungkinkan pemegang hak untuk melindungi materinya di pengadilan, membuat penulis memenuhi syarat untuk menerima ganti rugi menurut undang-undang, dan memberikan catatan publik tentang klaim hak cipta.

Hak cipta merupakan benda objek jaminan, khususnya jaminan fidusia berdasarkan ketentuan pasal 16 ayat 3 UU No. 28 Thn 2014 yang berisi pernyataan yaitu“Hak Cipta dapat dijadikan sebagai objek jaminan fidusia".

Ketentuan diatas berkaitan erat dengan UU No.42 Thn 1999. Pasal 1 angka 2 UU No.42 Thn 1999 menjelaskan pengertian dari jaminan fidusia yang di interpretasikan bahwa pengertian dari jaminan fidusia merupakan hak untuk menjaminkan benda yang tidak bisa bergerak, baik intangible (tidak berwujud) ataupun tangible (berwujud) dalam hal ini secara spesifik ditujukan pada bangunan yang dapat dijadikan hak tanggungan seperti dicantumkan dalam UU No. 4 Tahun 1996. Pada umumnya penyerahan jaminan utang yang dipersyaratkan untuk pemberi pinjaman dan merupakan satu kewajiban dasar, dimana jaminan bisa dalam bentuk barang (benda) ataupun dalam bentuk kesepakatan penanggungan utang. Seperti halnya objek jaminan utang yang biasanya diaplikasikan pada perjanjian utang-piutang. Dimana pemberi fidusia tetap mempunyai penguasaan penuh pada benda yang dijaminkan ketika digunakan untuk melunasi hutang piutang, yang diutamakan posisinya adalah untuk penerima fidusia daripada kreditur yang lain. ${ }^{8}$

Hak cipta sebagai objek jaminan fidusia belum memiliki peraturan yang lebih mengkhusus atau merinci terkait tata cara pemberian jaminannya. Sebagai dasar hukum penguat agar objek jaminan yang berupa hak cipta harus mempunyai unsurunsur yang mengatur perjanjian secara lengkah. Hak cipta sebagai jaminan, bentuknya adalah suatu perjanjian yang mana pengertian perjanjian menurut pasal 1313

\footnotetext{
7 A Fauzi, "Eksistensialisme Jaminan Pada Pendanaan Bank," Jurnal Hukum Islam Dan Pranata Sosial Islam 2, no. 1 (2010): 80-91.

${ }^{8}$ M Yasir, “Aspek Hukum Jaminan Fidusia,” Jurnal Sosial \& Budaya Syariah 5, no. 1 (2016): 30-42.
} 
KUHPerdata yaitu bahwa perjanjian merupakan satu kesepakatan yang melibatkan beberapa individu yang saling bersepakat.

Di dalam suatu perjanjian khususnya perjanjian kredit terkait dengan hak cipta sebagai jaminan yang merupakan suatu perjanjian ikutan dari perjanjian pokok, maka tentunya hak cipta sebagai objek jaminan dari perjanjian pokok menurut pasal 1320 KUHPerdata.

Untuk mengetahui sah atau tidaknya suatu perjanjian yang dalam hal ini hak cipta sebagai jaminan kredit dapat merujuk pada pasal 1320 KUHPerdata yaitu memerlukan empat hal pokok yang dapat diartikan sebagai berikut:

1. Beberapa pihak yang sepakat untuk mengikatkan diri;

2. Bahwa orang-orang yang membuat perjanjian mempunyai kecakapan;

3. Satu hal khusus;

4. Sebab dibuatnya perjanjian tidak terlarang atau halal.

Menurut empat peryaratan yang telah disebutkan, maka adanya kesepakatan dan juga kecakapan untuk membuat perjanjian merupakan persyaratan yang subjektif, artinya jika tidak lengkap syarat-syarat tersebut diatas maka perjanjian bisa dibatalkan. Sementara satu hal khusus dan sebab yang halal bersifat objektif, artinya jika persyaratan tersebut tidak dipenuhi maka kesepakatan yang dilaksanakan menjadi batal demi hukum. ${ }^{9}$ Maka terkait hak cipta sebagai jaminan kredit, pasal 1320 dapat digunakan.

Dalam membuat suatu perjanjian, tentu akan menimbulkan suatu prestasi dan kontra prestasi oleh kedua belah pihak yang mengikatkan dirinya. Pasal 1338 KUHPerdata dapat diinterpretasikan maknaya sebagai berikut yaitu bahwa seluruh kesepakatan yang dilakukan adalah sah menurut undang-undang yang berlaku untuk mereka yang terlibat dalam perjanjian. Tidak ada perjanjian yang dapat ditarik kembali tanpa persetujuan para pihak yang terlihat terlebih dahulu. Dan dapat diakhiri jika undangundang menyatakan alasan yang diberikan sudah cukup. Perjanjian yang dilakukan antara para pihak harus dilakukan dengan itikad yang baik bagi keduanya. Maka, dalam suatu perjanjian para pihak harus melaksanakannya dengan semestinya serta dengan itikad baik.

Hak cipta memiliki dua hak yakni; hak ekonomi dan hak moral. Hak ekonomi merupakan hak mendapat kegunaan ekonomi dari hak cipta dan juga produk yang berkaitan, hak ini dapat dipindahtangankan secara keseluruhan ataupun sebagian menurut peraturan dan metode yang dijelaskan dalam pasal 16 ayat 2 UU. No. 28 Thn 2014 dapat diinterpretasikan maknanya bahwa hak cipta dapat dipindah tangankan, dialihkan, kepada orang lain atau pihak yang berhak, secara sebagian ataupun keseluruhan disebabkan alasan pewarisan, sebagai wakaf, kesepakatan, hibah, perjanjian lisan atau tulisan, atau hal lain yang dapat dibenarkan menurut aturan dan undang-undang yang berlaku. Hak moral dimiliki seorang individu yang membuat karya cipta ataupun penciptanya yang tidak bisa dihapus ataupun ditiadakan tanpa

\footnotetext{
${ }^{9}$ Lastuti Abubakar and Tri Handayani, "Telaah Yuridis Perkembangan Regulasi Dan Usaha Pergadaian Sebagai Pranata Jaminan Kebendaan,” Jurnal Bina Mulia Hukum 2, no. 1 (2017): 80-92.
} 
alasan apapun, meskipun sudah dilakukan peralihan hak cipta tersebut kepada pihak lainnya. ${ }^{10}$

UU No.42 Thn 1999 menjelaskan pengertian dari fidusia sebagai pemindahan hak kepemilikan suatu barang dengan didasari unsur kepercayaan dengan syarat bahwa benda tersebut tetap menjadi milik dari pemilih benda walaupun hak kepemilikannya telah. Pasal 1 angka 2 UU No.42 Thn 1999 menjelaskan pengertian dari jaminan fidusia yang berbunyi yang di interpretasi bahwa pengertian dari jaminan fidusia merupakan hak untuk menjaminkan benda yang tidak bisa bergerak, baik intangible(tidak berwujud) ataupun tangible (berwujud) dalam hal ini secara spesifik ditujukan pada bangunan yang dapat dijadikan hak tanggungan. Dimana pemberi fidusia tetap mempunyai penguasaan penuh pada benda yang dijaminkan ketika digunakan untuk melunasi hutang piutang, yang diutamakan posisinya adalah untuk penerima fidusia daripada kreditur yang lain.

Didalam proses melakukan penilaian pada benda yang akan digunakan sebagai jaminan dan dibebankan oleh lembaga penjamin, selama ini lazim praktek dilapangan yaitu, lembaga keuangan yang memberikan dana (kreditur), dengan bantuan appraisal yaitu pihak ketiga yang bertugas untuk menunjang dalam sektor finansial, dan dapat memberikan penilaian mengenai nilai ekonomi benda dan pengukurannya secara profesional, dan selanjutnya dibebani dengan lembaga jaminan. Permenkeu Indonesia No.101/PMK.01/2014 secara khusus mengatur tentang profesi appraisal ini. Defenisi penilai menurut Peraturan ini merupakan individu yang berkompetensi untuk melakukan satu Penilaian yang sudah mendapatkan lisensi dari Menteri untuk menyediakan layanan seperti disebutkan dalam Peraturan Menteri tersebut.

Menurut Ketentuan 15/PBI/2012 Tentang Penilaian Kualitas Aset Bank Umum Pasal 43, jaminan yang dapat dinilai atau dihitung adalah sebagai berikut:

a. Surat Saham yang masih bisa diperjualbelikan dibursa saham;

b. Bangunan dan lahan yang bisa dijadikan jaminan;

c. Mesin atau peralatan yang bisa dijadikan jaminan;

d. Pesawat atau kapal berukuran lebih dari 20 (dua puluh) $\mathrm{m}^{3}$ yang dibebani dengan hipotek;

e. Kendaraan yang mempunyai beban fidusia.

f. Resi gudang yang bisa dijadikan jaminan. ${ }^{11}$

Untuk Hak Cipta hingga saat ini selain belum masuk dalam daftar jaminan, tidak ada juga pedoman untuk menilai yang dapat diterapkan oleh Penilai Publik, maka dari itu Hak Cipta masih ditolak oleh lembaga keuangan untuk digunakan sebagai jaminan. Peraturan pemerintah yang lebih lanjut mengatur tentang metode pengikatan fidusian untuk Hak Cipta masih belum dibuat.

Di Indonesia sendiri UU Hak Cipta sudah diatur dalam Lembaga Manajemen Kolektif. Dimana lembaga ini bersifat nirlaba yang diberikan kuasa oleh pemilik hak cipta, atau orang yang menciptakan dan ataupun orang yang berhak atas hak cipta untuk mengatur nilai hak ekonomi dari hasil ciptaannya dengan cara mengumpulkan atau menyebarkan royalti.

\footnotetext{
${ }^{10}$ V. A Riandini, "Pelelangan Hak Jaminan Di KPKNL Terhadap Kreditur Bank," Jurnal Ilmiah Widya 4, no. 2 (2015).

${ }^{11}$ Muhammad Maksum, "Penerapan Hukum Jaminan Fidusia Dalam Kontrak Pembiayaan Syariah,” 2015.
} 
Lembaga Manajemen Kolektif ini dapat memfasilitasi usaha Penilai Publik untuk memberikan penilaian pada Hak Cipta, yakni dengan menyerahkan data jumlah royalti resmi yang didapatkan oleh pemegang Hak Cipta dalam waktu yang telah ditentukan, untuk dipergunakan sebagai bahan pertimbangan lain untuk mengukur Hak Cipta dari segi nilai ekonomisnya.

Selain nilai ekonomis suatu Hak Cipta, juga tidak mudah untuk menetapkan orang yang mempunyai hak sebagai Pemberi Fidusia. Walaupun untuk Hak Cipta, perlindungan yang digunakan menerapkan sistem deklaratif atau perlindungan yang tidak mengharuskan adanya pendaftaran, namun dalam rangka menghasilkan perlindungan yang kuat terhadap Hak Ekonomi atas karya ciptaannya, dengan demikian para pencipta disarankan untuk mencatatkannya kepada Dirjen HAKI Kemenkumham untuk menentukan pihak yang mempunyai hak menjadikan Hak Cipta sebagai objek jaminan dengan kepastian hukum yang sah.

Menurut penjelasan diatas, berkaitan dengan masih belum dibuatnya peraturan tentang mekanisme penentuan fidusia lebih lanjut untuk Hak Cipta, maka ketentuan yang dapat diterapkan untuk difungsikan menjadi landasan pengukuran nilai ekonomis dari sebuah karya cipta agar dapat dimanfaatkan sebagai objek fidusia, yaitu;

a. Hak Cipta harus telah dicatatkan pada Dirjen HAKI Kemenkumham Indonesia

b. Dengan perkiraan nilai ekonomis yang bisa dipertanggungjawabkan, bisa diketahui berdasarkan nilai kontrak untuk mengedarkan atau memanfaatkan atau menampilkan hasil karya cipta tersebut

c. Hak cipta tersebut dipegang oleh Lembaga Manajemen Kolektif, yang dengan demikian nilai royalti telah ditetapkan.

d. Besaran kredit yang diberikan harus dilakukan dengan prinsip kehati-hatian yaitu jumlah kredit, tujuan dan jangka waktu harus menurut ketentuan BI dan atau OJK.

e. Sertifikat HAKI sudah termasuk sebagai objek jaminan untuk memperoleh pinjaman dari lembaga perbankan.

f. Memberikan jaminan dalam bentuk berbeda yaitu jaminan personal guarantee atau borgtocht terhadap pihak yang menggunakan karya yang diciptakan, misal lagu ciptaan seseorang ${ }^{12}$

Hak cipta dapat dijaminkan bila ada kesepakatan antara pihak yang bersangkutan. Bilamana ada diantaranya yang tidak bersedia, maka perjanjian tersebut tidak akan dapat berlangsung.

\subsection{Mekanisme Pengeksekusian Hak Cipta Jika Debitur Wanprestasi}

Apabila debitur cedera janji, maka menurut Pasal 15 ayat (3) UU 42 No. 1999 tentang Jaminan Fidusia, kreditur (penerima fidusia) mempunyai hak untuk menjual benda yang menjadi objek jaminan fidusia atas kekuasaannya sendiri. Namun patut diperhatikan bahwa frasa "cedera janji" bertentangan dengan Undang-Undang Dasar Negara Republik Indonesia Tahun 1945 dan tidak mempunyai kekuatan hukum

\footnotetext{
${ }^{12}$ Nazia Tunisa, "Peran Otoritas Jasa Keuangan Terhadap Pengawasan Pendaftaran Jaminan Fidusia," Jurnal Cita Hukum 2, no. 2 (2015): 40845.
} 
mengikat sepanjang tidak dimaknai bahwa adanya cedera janji tidak ditentukan secara sepihak oleh kreditur melainkan atas dasar kesepakatan antara kreditur dengan debitur atau atas dasar upaya hukum yang menentukan telah terjadinya cedera janji. Hal ini sebagaimana diputus oleh Mahkamah Konstitusi dalam Putusan Mahkamah Konstitusi Nomor 18/PUU-XVII/2019.

Selain itu, menurut Frieda Husni Hasbullah dalam bukunya Hukum Kebendaan Perdata: Hak-hak yang Memberi Jaminan, salah satu ciri jaminan fidusia adalah kemudahan dalam pelaksanaan eksekusinya, yaitu apabila setelah melalui kesepakatan para pihak, pihak pemberi fidusia cedera janji. ${ }^{13}$ Oleh karena itu, dalam UU Jaminan Fidusia dipandang perlu diatur secara khusus tentang eksekusi jaminan fidusia melalui lembaga parate eksekusi. Apabila debitur atau pemberi fidusia, setelah disepakati para pihak, dipandang cedera janji (wanprestasi), eksekusi terhadap objek jaminan fidusia dapat dilakukan dengan cara yang terdapat dalam Pasal 29 ayat (1) UU 42 No. 1999 tentang Jaminan Fidusia, yaitu:

1. Pelaksanaan Titel Eksekutorial

Titel eksekutorial ini mengacu pada Pasal 15 ayat (2) UU Jaminan Fidusia bahwa segala mekanisme dan prosedur hukum dalam pelaksanaan eksekusi sertifikat jaminan fidusia harus dilakukan dan berlaku sama dengan pelaksanaan eksekusi putusan pengadilan yang telah berkekuatan hukum tetap, jika tidak ada kesepakatan cidera janji dengan debitur yang juga keberatan menyerahkan objek jaminan fidusia.

2. Menjual Melalui Pelelangan Umum

Ketentuan Pasal 29 ayat (1) huruf b UU 42/1999 merupakan pelaksanaan Pasal 15 ayat (3) UU 42/1999 bahwa cidera janji diartikan harus ditentukan atas dasar kesepakatan antara kreditur dengan debitur atau atas dasar upaya hukum yang menentukan telah terjadinya cidera janji sebelum melakukan pelelangan umum serta mengambil pelunasan piutangnya dari hasil penjualan tersebut.

3. Penjualan di Bawah Tangan

Sesuai dengan Pasal 29 ayat (1) huruf c UU 42/1999, penjualan di bawah tangan dilakukan berdasarkan kesepakatan pemberi dan penerima fidusia jika dengan cara demikian dapat diperoleh harga tertinggi yang menguntungkan para pihak. Pelaksanaan penjualan dilakukan setelah lewat waktu satu bulan sejak diberitahukan secara tertulis oleh pemberi dan penerima fidusia kepada pihak-pihak yang berkepentingan dan diumumkan sedikitnya dalam dua surat kabar yang beredar di daerah yang bersangkutan

Pemberi fidusia wajib menyerahkan benda yang menjadi objek Jaminan Fidusia dalam rangka pelaksanaan eksekusi Jaminan Fidusia. Dalam hal benda yang menjadi objek jamiman fidusia terdiri atas benda perdagangan atau efek yang dapat dijual di pasar atau di bursa, penjualannya dapat dilakukan di tempat-tempat tersebut sesuai dengan peraturan perundang-undangan yang berlaku. Setiap janji untuk melaksanakan eksekusi terhadap benda yang menjadi objek Jaminan Fidusia dengan cara yang bertentangan dengan ketentuan, batal demi hukum. Setiap janji yang memberi kewenangan kepada penerima fidusia untuk memiliki benda yang menjadi objek

${ }^{13}$ J Satrio, "Hukum Jaminan Hak Jaminan Kebendaan,” Bandung: PT. Citra Aditya Bakti, 2007. 
Jaminan Fidusia apabila debitur cidera janji, batal demi hukum. Dalam hal hasil eksekusi melebihi nilai penjaminan, penerima fidusia wajib mengembalikan kelebihan tersebut kepada pemberi fidusia. Apabila hasil eksekusi tidak mencukupi untuk pelunasan utang debitur tetap bertanggung jawab atas utang yang belum terbayar. ${ }^{14}$

Hak Cipta tidak dapat disita karena melekat pada diri pemegang Hak Cipta. Hal ini berarti hukum melindungi kepemilikan seseorang sesuai dengan teori hukum alam yang menghargai dan menghormati hasil karya intelektual manusia. Selain itu, perlindungan Hak Cipta tidak ditujukan kepada bendanya, tetapi kepada Hak Cipta atas benda tersebut. Dengan demikian tidak dapat dilakukan eksekusi Hak Ciptanya sebagai dasar pengakuan hak asasi manusianya. Hal yang mungkin dapat dilakukan adalah mengeksekusi nilai ekonomi dari Hak Cipta tersebut atau penjualan nilai ekonomi yang menjadi objek Jaminan Fidusia atas kekuasaan penerima fidusia sendiri melalui pelelangan umum serta mengambil pelunasan piutangnya dari hasil penjualan, atau penjualan di bawah tangan yang dilakukan berdasarkan kesepakatan pemberi dan penerima fidusia, dengan menggunakan perjanjian tertulis sebagaimana aturan pengalihan Hak Cipta pada Pasal 16 ayat 2 UUHC Tahun 2014 sehingga nantinya pihak penerima fidusia dapat diperoleh harga tertinggi yang menguntungkan bagi para pihak. Sehingga ketentuan dalam UUHC Tahun 2014 mengenai penggunaan Hak Cipta dapat dijadikan sebagai objek Jaminan Fidusia telah sesuai dengan UU No. 42 tahun 1999 tentang Jaminan Fidusia.

\section{Kesimpulan}

Hak Cipta sebagai objek jaminan fidusia telah sesuai dengan Undang-Undang Nomor 42 Tahun 1999 Tentang Jaminan Fidusia dimana Hak Cipta dapat dibebani jaminan dalam bentuk fidusia, tetapi bukan pada benda yang dibebani Hak Cipta tersebut, melainkan nilai ekonomi yang melekat pada hak cipta tersebut. Selain itu, Hak Cipta tersebut harus didaftarkan terlebih dahulu ke Direktorat Jenderal Kekayaan Intelektual, Kementerian Hukum dan HAM sebelum dapat dijaminkan. Hal ini penting karena sebagai bukti bahwa pemberi fidusia adalah pemegang Hak Cipta tersebut. Penentuan nilai ekonomi pada Hak Cipta dapat dihitung dengan beberapa model perhitungan benda yang sifatnya immateriil, tentunya pihak bank atau lembaga keuangan yang menerima Hak Cipta sebagai objek Jaminan Fidusia mempunyai tim khusus untuk menilai besaran nilai ekonomi pada suatu ciptaan. Nilai ekonomi akan ditentukan oleh pengetahuan dan keyakinan pejabat penilai yang diberi tugas bank untuk menaksir atau menilai Hak Cipta. Seperti juga jaminan fidusia, yang mengedepankan aspek kepercayaan antara debitur (pemilik Hak Cipta) dan kreditur. Perlu adanya sosisalisasi dari Pemerintah atas dikeluarkanya Undang-Undang Nomor 28 Tahun 2014 Tentang Hak Cipta khususnya Pasal 16 ayat 3 mengenai Hak Cipta dapat dijadikan sebagai objek jaminan fidusia kepada masyarakat, sehingga masyarakat mengetahui bahwa sebuah karya cipta dapat dijadikan sebagai objek jaminan fidusia.

Perlu adanya Peraturan Pemerintah mengenai aturan pelaksanaan Hak Cipta sebagai objek Jaminan Fidusia; Bagi lembaga fidusia perlu adanya tim khusus yang menghitung hak ekonomi pada Hak Cipta sehingga Hak Cipta dapat diketahui nilai ekonominya. Adanya tim khusus yang menilai hak ekonomi pada suatu Hak Cipta

\footnotetext{
${ }^{14}$ E Damian, Hukum Hak Cipta. Bandung : Alumni. h.24 (Bandung: Alumni, 2002).
} 
dituntut agar lebih terbuka, pangsa pasar juga turut menentukan penilaian terhadap Hak Cipta, sehingga nantinya akan berguna bagi kreditur apabila debitur terjadi wanprestasi.

\section{Daftar Pustaka}

Abubakar, Lastuti, and Tri Handayani. "Telaah Yuridis Perkembangan Regulasi Dan Usaha Pergadaian Sebagai Pranata Jaminan Kebendaan." Jurnal Bina Mulia Hukum 2, no. 1 (2017): 80-92.

Damian, E. Hukum Hak Cipta. Bandung : Alumni. h.24. Bandung: Alumni, 2002.

Fauzi, A. "Eksistensialisme Jaminan Pada Pendanaan Bank." Jurnal Hukum Islam Dan Pranata Sosial Islam 2, no. 1 (2010): 80-91.

M Bahsan SH, S E. Hukum Jaminan Dan Jaminan Kredit Perbankan Indonesia. Rajawali pers, 2020.

Maksum, Muhammad. "Penerapan Hukum Jaminan Fidusia Dalam Kontrak Pembiayaan Syariah," 2015.

Riandini, V. A. "Pelelangan Hak Jaminan Di KPKNL Terhadap Kreditur Bank." Jurnal Ilmiah Widya 4, no. 2 (2015).

Satrio, J. “Hukum Jaminan Hak Jaminan Kebendaan." Bandung: PT. Citra Aditya Bakti, 2007.

Setianingrum, Reni Budi. "Mekanisme Penentuan Nilai Appraisal Dan Pengikatan Hak Cipta Sebagai Objek Jaminan Fidusia." Jurnal Media Hukum 23, no. 2 (2016): 229-38.

Sitanggang, Bhinneka Wahyudi Palito. “ROYA PARTIAL TERHADAP OBYEK HAK TANGGUNGAN DALAM PERJANJIAN KREDIT KONSTRUKSI DI PT. BANK NEGARA INDONESIA (PERSERO), Tbk, KANTOR CABANG SEMARANG." UNIVERSITAS DIPONEGORO, 2010.

Sudjana. "Perlindungan Hak Cipta Menurut UU. No. 28 Tahun 2014 Berdasarkan Sudut Pandang Cyber Law." Jurnal Fakultas Hukum Universitas Katolik Parahyangan 9, no. 2 (2016): 1-5.

Tunisa, Nazia. "Peran Otoritas Jasa Keuangan Terhadap Pengawasan Pendaftaran Jaminan Fidusia." Jurnal Cita Hukum 2, no. 2 (2015): 40845.

Yasir, M. "Aspek Hukum Jaminan Fidusia." Jurnal Sosial \& Budaya Syariah 5, no. 1 (2016): 30-42.

Yudistira, Made Bagus Satria. “Pengaturan Hukum Sertifikat Hak Atas Merek Sebagai Jaminan Fidusia Dalam Proses Pengajuan Kredit Di Perbankan Berdasarkan Undang-Undang Nomor 20 Tahun 2016." Jurnal Magister Hukum Udayana (Udayana Master Law Journal) 6, no. 3 (2017): 310-22.

\section{Peraturan Perundang-Undangan}

Kitab Undang-Undang Hukum Perdata, Burgelijk Wetboek voor Indonesie, Staatsblad Tahun 1847 Nomor 23.

Undang-Undang Nomor 42 tahun 1999 tentang Jaminan Fidusia, Tambahan Lembaran Negara Republik Indonesia Nomor 5952

Undang-Undang Nomor 28 Tahun 2014 tentang Hak Cipta, Tambahan Lembaran Negara Republik Indonesia Nomor 5599 